\title{
Organ Measurements Collection Date Time
}

National Cancer Institute

\section{Source}

National Cancer Institute. Organ Measurements Collection Date Time. NCI Thesaurus.

Code C119884.

The date and time of organ measurements data collection. 